\title{
'The house is hers, the soul is but a tenant': Material Self- Fashioning and Revenge Tragedy
}

In Thomas Middleton's The Maiden's Tragedy, the Lady, object of interest for Govianus and the Tyrant, appears on stage as a ghost together with her corpse. ${ }^{1}$ Indeed, the Lady appears twice with her corpse. She first appears as a ghost dressed in her virginal burial garb with a crucifix, while her corpse has been bedecked in a different elaborate dress and jewels; the stage directions prior to her entrance read, 'Enter the Ghost of the Lady, as she was / Last seen, standing just before him all in white, stuck with / Jewels, and with a great crucifix on her breast' (4.5.43). The Lady's second appearance on stage is even more fraught, since she next appears on stage as a ghost dressed in the very same garb as her corpse: 'Enter the Ghost of the Lady, dressed in the same form as her body in the chair' (5.2.143). For many scholars this instance follows a prevailing motif of revenge tragedies, in which ghosts and corpses problematize 'playing dead'. ${ }^{2}$

Playing dead, however, is not merely a staging issue, though performance of a single character in two simultaneous but separate locations is a legitimate concern, both metaphysical and staging, since playing dead also poses eschatological and ontological challenges to neoplatonism, stoicism, and Christian theology, frameworks within which many Jacobean and revenge plays are conceived. Where most readings of ghosts and corpses on stage rely on a Christian, neoplatonic, and stoic notion of the body's unity with the soul, in which the soul governs the body and the body is a mere vessel for the soul, I argue that The Maiden's Tragedy, The Revenger's Tragedy, and The Duchess of Malfi all participate in a larger trend of the early modern period in which the body is progressively evacuated of the spirit. This progression ultimately reverses the conventional Christian and neoplatonic paradigm, such that the material, the body, is shown to govern the spirit, and the body itself demonstrates an unruly agency that troubles both a stable and 'whole' conception of the self, as well as a notion of the soul/self as indivisible from 
the body until after death. All three plays anticipate Cartesian mechanistic dualism where consciousness constitutes subjectivity and where bodies can be automata.

The very medium of theatre itself works to undermine neoplatonism and stoicism, in that theatricality effectively destabilizes the spirit's immanence in the body, as it demands materialism both in staging and in reading. What is more, the mode of theatre is connected with the Cartesian cogito, which also insists upon a kind of detached theatricality, what Erica Harth calls a 'theatrum mundi' and what Gordon Braden calls 'a privileged position from which to observe and delineate. ${ }^{3}$ Thus, as we move from plays of the late Elizabethan period to the Jacobean period, which call increasingly for theatricality, we witness a progressive evacuation of the spirit from the body, to the extent that the material and not the spiritual is the governing force of the body. Not only does the body precede and govern the soul, but also modifications to the body effect modifications to the soul. ${ }^{4}$

That corporeal modifications are a subject of this article in the first place arises in part because a discussion of Jacobean and revenge tragedies demands a discussion of bodily modifications. For many scholars, the early modern body can be described by Elaine Scarry's notion: 'We today generally assume that the body should be thought of "as a whole" rather than as "parts", since the latter seems to imply an aggressive, if only mentally executed, dismemberment. ${ }^{5}$ Indeed, this premise, neoplatonic and stoic at heart, proves to be the underlying impetus for revenge, even if the outcome challenges this motivation in the first place. The concept of revenge is itself bound up with corporeal fashioning in that the body is frequently the locus for revenge, where dismemberment is not merely mental, but actual and staged. Revenge plays follow the historical trajectory I suggest above in that Elizabethan plays feature 'humanistic' revenge, in which bodies have organs removed, limbs severed, or other bits taken off, but still privilege the body as human with an immanent soul. The Spanish Tragedy has a severed tongue and Titus Andronicus has severed hands, heads, and a tongue. In Titus, Titus's hand is cut off both to signal his loss of agency and to deprive him of his literal power to use his hand.

Jacobean plays, however, feature the modification of a body in its totality, either through the use of a corpse, or the deployment of a 'false' body or a simulacrum. In these instances bodily modifications also culminate in a surprising inversion of power when the modified body gains the upper hand. In The Maiden's Tragedy a corpse is disinterred, sexually violated, painted with cosmetics and dressed in at least two changes of clothes. In The Duchess of 
Malfi wax figures replace the bodies of Antonio and the children. In The Revenger's Tragedy, Vindice exacts revenge on the Duke by dressing a skeleton up like a prostitute and poisoning the mouth of the skull. The Duke, in a moment of grotesque comedy, overcome with desire, pounces on the bait to meet his end. This moment demonstrates a crisis of power in which the object of desire and control (and literally an object at that) suddenly has the advantage. Gloriana, the fashioned skeleton, gains control when 'her' poisoned lips effectively kill the Duke. Thus these plays epitomize the power and identity crises at stake in bodily fashioning, where bodies devoid of souls (still) possess agency. As corporeal fashioning mutates into something more disturbing, the body's ties to the spirit are increasingly threatened, and the conception of human itself is challenged.

\section{Senecan Stoicism, The Spanish Tragedy, and the Soul}

The Senecan mode, of which The Spanish Tragedy is a good representative, predominates in early revenge plays. A discussion of Senecanism is thus necessary to understand the ways in which the body-soul connection is ruptured in these plays. Such a mode is most evident in the characterization of the avengers or revengers. ${ }^{6}$ Commonly of a lower status than those upon whom they seek to take revenge, avengers often posses characteristics such as virtue and independence of spirit. The world that avengers occupy, which is responsible for their subordination, is regularly shown to be corrupt. Thus revenge is both symptomatic of class differences and the desire of the revenger to either prove his worth or free himself from various kinds of bondage (lower status, servitude). Class differences that initially prevent avengers from being able to do anything to effect justice heighten the compulsion for revenge later on. Avengers who feel that those in power have not done anything to provide justice end up taking matters into their own hands, often quite literally.

Seneca is perhaps most famous for ideas about bondage and freedom with respect to selfhood and the body, asserting that the soul is enslaved in 'serfdom on earth' in the body:

For that body is all that is vulnerable about me: with this dwelling so liable to injury there lives a spirit that is free... . I shall dissolve our partnership when this seems the proper course, and even now while we are bound one to the other the partnership will not be on equal terms: the soul will assume undivided authority. Refusal to be influenced by one's body assures one's freedom. ${ }^{7}$ 
In this sense, the soul trapped in the body mirrors the avenger, entrenched in servitude. ${ }^{8}$ Antonio and the Duchess (of The Duchess of Malfi), and Hieronimo and his wife Isabella (of Spanish Tragedy), are all to varying degrees Senecan stoics. The Duchess is often described as a 'caged bird,' a common metaphor for the soul trapped in a body. Similarly Isabella laments,

\author{
My soul? Poor soul, thou talk'st of things \\ Thou knowest not what - my soul hath silver wings, \\ That mounts me up unto the highest heavens. \\ To heaven! Aye, there sits my Horatio, \\ Backed with a troop of fiery cherubims, \\ Dancing about his newly healed wounds.
}

In fact, Isabella demonstrates herself to be a better stoic than Hieronimo, since Hieronimo's desire for revenge compromises his status as a virtuous avenger. Similarly, In Middleton's Maiden's Tragedy both the Tyrant and Govianus parrot Senecan philosophy. The very name 'Tyrant' aligns him with Nero, so that we expect a traditionally Senecan play.

Senecan stoicism in the early modern period is complicated by ongoing theological debates. Catholicism's concerns about bodily wholeness, even after death, are contingent on a belief in the spirit's immanence in the flesh. Thus, where ghosts in Jacobean plays demonstrate interests in their former bodies, some have interpreted this to be evidence of a lingering Catholic belief. ${ }^{9}$ Rather, as the body is progressively modified it increasingly empties of the spirit. What appears in these plays to be a concern for the soul is in fact a concern for the body alone. Critics are also divided about the extent to which these plays and the genre of revenge tragedy itself are orthodox in their subscription to Protestantism. ${ }^{10}$ In all English revenge tragedies, however, principles of religious orthodoxy and stoicism, which acknowledge God's will and divine justice, are undermined by the often hyperbolic natures of the revenge. ${ }^{11}$ Alongside this commonplace notion, however, we must also consider the role of the materially fashioned or modified body and the ontological and eschatological implications of bodily modification.

In Kyd's play the modified body does not actually align with Hieronimo's moral debasement, because Hieronimo, for all his fantasies of a corporeal revenge, relies on 'humanistic' revenge rather than bodily fashioning in killing Horatio. He demands that the kings view a common humanity in seeing their dead sons as equal to Hieronimo's. Maus writes, 
Ranging the corpse of his socially inferior son alongside the bodies of the heirs apparent, Hieronimo stages ... a radically levelling statement: that one dead child is very like another, that paternal love feels essentially the same for noble and commoner, that his suffering is worth as much as the suffering of princes... . Hieronimo's strict talion ... ignores disparities between one person and another, insisting upon equivalence and substitutability. ${ }^{12}$

But the substitutability that Maus elucidates is not the same kind that occurs in The Revenger's Tragedy and The Maiden's Tragedy; for Hieronimo's kind of substitution inspires sympathy. Horatio's body functions as a 'memento mori', reminding people of their own mortalities and his death, while The Revenger's Tragedy, The Duchess of Malfi, and The Maiden's Tragedy challenge conceptions of 'deadness' itself, featuring modified bodies that possess agency beyond life, agency absent of a soul. In order for the King and Viceroy to recognize the parallel deaths connecting Horatio (Hieronimo's only heir) and their now-lost heirs, Hieronimo must simply show the three sons side-by-side as dynastic dead ends. His 'levelling' depends on the 'naturalness' and sameness of the bodies

\section{The Cogito, and Theatrum Mundi, and Agrippa's Automata}

Despite an historical remove from Descartes, these plays also anticipate the foundation for 'modernity': a Cartesian mind and body separation. Two important distinctions must be made between Seneca and Descartes, especially since Descartes is often described as 'neo-Senecan'. Like Plato and Seneca, Descartes distinguishes between the material and ideal, separating body and mind, or body and soul. ${ }^{13}$ And like Seneca, Descartes believes the mind and soul are connected with God. But for Descartes, God is actually the Divine Mind: God's consciousness and imagination creates and governs the rest of the world both material and ideal. Whereas Seneca's separation of body and soul comes out of necessity and hardship, however, Descartes' separation is more aloof and privileged: 'the Cartesian cogito is not sought as a Stoic escape from its surroundings, but as a privileged position from which to observe and delineate them with new clarity'. ${ }^{14}$ Erica Harth describes Descartes's conception as a 'theatrum mundi':

Descartes's neostoicism rests on the major epistemological premise that res cogitans has a reflexive capacity to disengage itself from the body (to which, we remember, 
it is attached, while nevertheless distinct) to view it and all that befalls it, and, consequently, all accidents that befall res extensa with the bemused detachment of a spectator at the theatre. ${ }^{15}$

In this sense, then, Hieronimo's staging of bodies foreshadows later plays, all of which depend on acts of staging the display of materially fashioned bodies for contemplation by an audience. Indeed, theatricality itself is the underlying principle which undermines stoicism in later plays, theatricality that effectively anticipates Cartesian mechanistic dualism and the cogito as a 'bemused spectator'. ${ }^{16}$ The cogito is thus distanced from its body and is in the place of the watcher whose view is both comprised of and insists upon the material. Vindice's characterization in The Revenger's Tragedy echoes this Cartesian position of bemused detachment and Vindice himself points it out constantly:

'tis my wonder

That such a fellow, impudent and wicked,

Should not be cloven as he stood, or with

A secret wind burst open.

Is there no thunder left, or is't kept up

In stock for heavier vengeance? [Thunder] There it goes!

(4.2.197-203 stage direction mine)

It is almost impossible for Vindice's quasi-moralistic stance not to elicit some kind of wry smile from a spectator/reader; and if that fails, Vindice's willingness to point out the artifice involved in the play lets the audience in on the joke, and makes him a 'bemused' spectator alongside them. That Vindice occupies a position of privilege is linked to his role as avenger and artificer. The same cannot be said of those whose bodies are corporeally fashioned.

Second, whereas for Senecan stoics a body cannot survive or exist without a soul, for Descartes, the body is a kind of machine that does not require the soul to live: 'death never comes to pass by reason of the soul, but only because some one of the principal parts of the body decays: and we may judge that the body of a living man differs from that of a dead man just as does a watch or other automaton (i.e. a machine that moves of itself)'. ${ }^{17}$ Thus, while the mind comprises the self, there is always the possibility of a separation of the body and mind. Descartes had great interest in the work of William Harvey, who proposed that the heart was akin to a pump and that the body itself 
was a kind of machine. ${ }^{18}$ According to Albert Howard Carter III, Descartes 'referred to Harvey's work' and considered that 'the god-given soul was different from sling and levers of the body... . [Descartes'] mixture of vitalism and mechanism kept the mind, the soul, and the brain separate from bodies, however, so that animals and humans were - at the level of the body basically the same'. ${ }^{19}$ What is more, living bodies are in effect no different from dead ones. Drew Leder writes that, for Descartes, 'the living body is not fundamentally different from the lifeless; it is a kind of animated corpse, a functioning mechanism'. ${ }^{20}$ Bodies are thus capable of possessing agency, capable of being without a field of consciousness. For Descartes, moreover, bodies and automata are equivalently material and real.

While there are few contemporaneously available philosophies to describe how the spirit is radically subordinated to the body in the way that these plays demonstrate, conceptions of automata emerge in the early modern period as early as 1530 with Cornelius Agrippa's De Vanitate Scientarum, a popular treatise on the occult, and Thomas Coryate's Crudities (1611), a famous travelogue of an Englishman's journey through Europe. ${ }^{21}$ Vanitate describes automata as lacking in spiritual immanence, and inspired by the devil. ${ }^{22} \mathrm{Pla}-$ tonic in his focus, Agrippa echoes early accounts of poetic creation, which privilege God and nature as creators over artificers who merely 'ape' nature to produce works that 'have not the vertues of the soule'. ${ }^{23}$ Agrippa's automaton is that which lacks a soul, but which is convincingly real because it relies on the powers of deception. In a chapter on 'Witchinge Magicke' Agrippa also describes acts of necromancy, which parody notions of resurrection, where dead bodies are 'rear'd' with no souls, suggesting the possibility of human automata, which possess agency even while they lack souls. ${ }^{24}$ In 1611, Coryate writes,

The manuary artes of the Venetians are so exquisite ... no artificers ... doe excel them... . I saw ... in a painters shop ... the picture of a hinder quarter of Veal hanged up in his shop, which a stranger at the first sight would imagine to be a naturall and true quarter of veal; but it was not: For it was only a counterfeit of a hinder quarter of veale, the rarest invention that ever I saw before... . I believe it

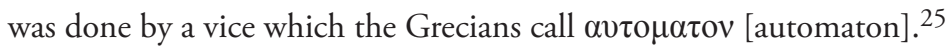

Coryate acknowledges the importance of both the artificer as agent of creation and the product of artifice, though his conception of automaton here, as with Descartes and Agrippa, still relies on the automaton's resemblance to 
something known, a 'hinder quarter of veale'. What is more, for Coryate the artificer here is a skilled craftsman, a role that degenerates into something more disturbing in Jacobean and revenge plays. The artificers in these plays, like Vindice and Govianus, apply their craft to the body in ways that challenge ultimately what it means to be human. ${ }^{26}$

\section{The Human Redefined: The Maiden's Tragedy, The Revenger's Tragedy and The Duchess of Malfi}

Revenge tragedies provide evidence of bodily agency, and the human automaton is an end point that several of the revenge tragedies reach, though not with ease. In The Maiden's Tragedy, The Revenger's Tragedy, and The Duchess of Malfi ideas about neoplatonism and Senecan stoicism give way to more radical ideas about the body that effectively anticipate Cartesian mechanistic dualism. For these plays suggest ultimately that acts of bodily modification divest the body of spiritual immanence; yet the body proves unruly, problematic, and, in The Maiden's Tragedy, ultimately contained.

In this play the central crisis of the body becomes apparent when the Lady's ghost and corpse appear on stage simultaneously. In addition, the Lady is figured in several ways which frustrate a sense of her self. Whereas in traditional Senecan plays dead characters figure as ghosts or corpses, who appear on stage separately, the Lady figures as the living Lady, the corpse of the Lady, the Lady's ghost, and the Lady's disembodied voice. The play's detachment from stoicism, however, is evident much earlier, especially in the characterizations of the villain and avenger who are both artificer figures. After the Tyrant laments the Lady's death initially, assuming that nothing can bring her back to life (4.2.26-36), he then proceeds to disinter her, his grief subsumed by a new fixation on her body: 'Death nor the marble prison my love sleeps in / Shall keep her body locked up from mine arms' (4.2.49-50). When she is untombed the Tyrant exclaims, 'O blessed object! / I shall never be weary to behold thee. / I could eternally stand thus and see thee' (4.4.59-61). The Lady becomes a statue of her former self and the Tyrant's desire for the lady a kind of pygmalionism, which is exacerbated by his desire to dress her up and paint her later on:

Since thy life has left me,

I'll clasp the body for the spirit that dwelt in't

And love the house still for the mistress' sake. 
But I'll unlock the treasure-house of art

With keys of gold and bestow all on thee. ${ }^{27}$

The pronoun references here emphasize the Tyrant's ambivalent treatment of the Lady as both object, 'the body', 'the house', and lover, using the intimate 'thee' instead of the more formal 'you'. The Lady's body is moreover a work of art, to be 'unlock[ed]' and fashioned to his liking. In addition, he continues to insist on her body's revival after it receives adornments and cosmetics::

\section{O, she lives again!}

She'll presently speak to me. Keep her up,

I'll have her swoon no more: there's treachery in't.

Does she not feel warm to thee?

For the Tyrant the Lady's corpse becomes progressively invested with material energy as it is increasingly modified.

The Tyrant's acts demonstrate his lack of concern for the Lady's spirit, and persistent investment in her body. Prior to the application of cosmetics by a disguised Govianus, in fact, the Tyrant has dressed up the Lady's corpse, propped it up in a chair, and bedecked it in jewels, not to mention handled and caressed it (at the very least). In addition he forces his soldiers to bow before the Lady's corpse, while he himself kisses her hand:

The house is hers, the soul is but a tenant.

I hatasked myself but with the abstinence

Of one poor hour, yet cannot conquer that.

I cannot keep from sight of her so long.

I starve mine eye too much. Go, bring her forth

As we have caused her body to be decked

In all the glorious riches of our palace.

Enter Soldiers, who bring in the body of the Lady in a chair, dressed up in black velvet (which sets out the paleness of her hands and face), and a fair chain of pearl across her breast, and the crucifix above it. The Tyrant stands silent awhile, letting the music play, beckoning the Soldiers, that bring her in 
to make obeisance to her, and he himself makes a low honour to the body and kisses the hand.

(5.2. 3-13)

Even the stage directions are complicit with the Tyrant, parallelling his ambivalent attitude toward the Lady's corpse, referring to it alternatively as 'her' and 'the body.' Moreover, the description of her black dress that sets off the paleness of her skin echoes Petrarchan conceptions of beauty, signalling a kind of life-in-death, but a liveliness that is wholly material and tangible, as opposed to divine and inaccessible. But the Tyrant is far from a good Petrarchan or Senecan lover, since his attitude towards the Lady and her body are encapsulated by his new claim that 'The house is hers, the soul is but a tenant', which effectively reverses the Senecan hierarchy of the soul and the body. Here, the soul is merely a temporary guest in the more material, more substantial, more accessible, and more desirable body of the Lady.

In his concern for the Lady's body the Tyrant is mirrored by Govianus, who, as the purported Senecan hero, is paradoxically the other artificer. Govianus's supposedly unwavering Senecanism is proven to be much like all of his other qualities, feckless, as he too worships the Lady's body for its own sake. Before Govianus degenerates completely, he touts stoicism, believing that the Lady is beyond supposed wrongdoings to her body after her suicide (4.5.56-57). Even during the Ghost's second appearance, Govianus claims that the Lady's body and spirit are now united, since the Tyrant has been foiled and since presumably the Lady's Ghost and her corpse are now in the same place (5.2.150-3). Govianus fails to understand that he too mistreats the Lady's body, and views the Lady's Ghost as indicative of her spirit, even though she tells him otherwise. Indeed, his primary motive for killing the Tyrant was to preserve the chastity of the Lady's body.

Like Vindice in The Revenger's Tragedy, Govianus's revenge depends upon a material fashioning of the Lady's corpse, since his application of poisoned cosmetics brings about the Tyrant's defeat. After avenging her honour, he ought presumably to make haste to get the Lady's unruly corpse buried, to unite her body and soul as a traditional Senecan hero would, but instead he, as the Tyrant does, adds to her outfit and changes her body's position once again, moving it out of the chair and into the throne, stating:

And since the body of that virtuous lady

Is taken from her, in memory

Of her admired mistress, 'tis our will 
It receive honour dead as it took part

With us in all affections when it lived.

Here place it in this throne, crown her our Queen,

The first and last that ever we make ours.

Govianus celebrates the Lady's body as a new queen, indicating that her body, more than her spirit, is important for this kind of signification. Now that the 'contest of masculinity' is over, Govianus marks his triumph materially. ${ }^{28}$

What is at stake for Govianus as hero is rightful possession of the Lady, a stake which both he and the Tyrant interpret as material. Thus this newly fashioned corpse of the Lady, fashioned by the Tyrant, is not the same as the one Govianus buried. What proves to matter most to Govianus is the status of the Lady's body as no longer 'chaste' since it has been violated materially and sexually by the Tyrant. Thus Govianus must change the Lady's body physically to erase the Tyrant's imprint. The Lady's Ghost's appearance confirms these suspicions about Govianus, since she reappears in the final lines of the play. While the Ghost's reappearance no doubt signals a reunification of the Lady's body with her soul, it also lays bare her mistrust of Govianus, who reacts defensively at her re-appearance: 'O welcome blessed sprit! / Thou needst not mistrust me. I have a care / as jealous as thine own... . Lead on' (196-201).

The Ghost's reappearance to police her corpse is motivated by more than one anxiety: first, a valid mistrust of Govianus, who might fail to bury her corpse, and who might alter her body even more. Second, the Ghost is driven by the same terror that compels her to ask Govianus for help in the first place: the fear that her corpse possesses a kind of residual animation, a capacity for material agency. Is the Ghost, then, where we locate the Lady's self? Both Govianus and the Tyrant's fixations on the Lady's corpse trouble the Lady's sense of self. Indeed, their modifications to her corpse provoke the Ghost's appearance. The only evidence we have of the Lady's self are in the figures of the Ghost, and the disembodied Voice, who both insist that the Lady's self inheres in her body. When Govianus visits the Lady's tomb, praising her for her chastity, the Lady's voice is heard, followed by the entrance of her Ghost:

Lady's Voice I am not here.

Govianus What's that? Who is not here? I'm forced to question it.

Some idle sounds the beaten vaults send forth. 
On a sudden, in a kind of noise like the wind, the doors

clattering, the tombstone flies open and a great light appears in

the midst of the tomb. Enter the Ghost of the Lady, as she was

last seen, standing just before him all in white, stuck with

jewels, and with a great crucifix on her breast.

If we are to believe the Lady, then she is clearly not here as the Ghost or as the Voice. And when we hear her voice again, she tells us where she actually is:

The peace that death allows me is not mine.

The monument is robbed: behold I'm gone,

My body taken up.

I am now at court

In his own private chamber. There he woos me

And plies his suit to me with as serious pains

As if the short flame of mortality

Were lighted up again in my cold breast,

Folds me with his arms and often sets

A sinful kiss upon my senseless lip.

$(66-72)$

The Ghost of the Lady, like Govianus and the Tyrant, demonstrates similar material concerns about her body, making a desperate appeal to Govianus to save her body from sexual violation.

For Anne Lancashire and Marion Lomax, the Ghost of the Lady is a Christ figure who aids Govianus in his quest as rightful ruler. ${ }^{29}$ There is no denying the Christian element to the Ghost's first appearance and her unhappiness with the desecration of her former body. As Susan Zimmerman points out, in the Protestant context in which this play is written, the Ghost's concerns reflect a Catholic anxiety about bodily desecration. Within a Senecan framework, however, the Lady's Ghost should not care about what is done to her body; her soul should be free, especially since she killed herself when she was chaste. Even if this moment illustrates Catholic concerns about corporeal integrity, it still troubles the Christian doctrine. The Ghost, who insists 'I am not here' is a distortion of Christ, who appears prior to resurrection, rather than after, and clings stubbornly to its former body. Thus the Lady's soul, her self, is not present in the Ghost and must still somehow be connected to her body. ${ }^{30}$ 
Matters of eschatology and ontology overlap here, complicating the boundaries between life, death, and consciousness, since there are three possible locations for the lady's self: her Voice, her Ghost, and her material corpse. The play's ambivalence about Christianity and stoicism culminates with the Ghost's second appearance, which occurs after Govianus has painted the Lady's face with poison and the Tyrant is poisoned by kissing her: 'Enter the Ghost of the Lady, dressed in the same form as her body in the chair.' Whereas previously the Ghost appeared in the clothes she was buried in (after and despite the fact that the Tyrant had bedecked her with jewels once already), the Ghost now wears the same 'black velvet' dress as the corpse in the chair. Zimmerman reads this moment (of the Ghost adopting the same wardrobe as the corpse), as symbolic of the Tyrant's 'depraved transformation [of the Lady's corpse] into the Tyrant's idol'. ${ }^{31}$ To frame the Tyrant's stance as idolatry, however, is still to accept that the material is infused with a spirit. Rather, the Tyrant is precisely a tyrant because he operates within a Senecan context; he is the corrupt ruler against whom the avenger must compete to rectify the world-at-large and to get the Lady. Thus the Tyrant, in stealing the Lady's body, assumes he has stolen the Lady herself. Yet his obsession remains on her body and not her soul. Moreover, the Lady's corpse has a kind of disruptive agency of which the Ghost is evidently aware and which is made clear by the corpse's power to change the immaterial form of the Ghost. Thus, the conventional paradigm has been turned on its head: the body of the Lady haunts her Ghost, or the material haunts the spirit.

Few in The Maiden's Tragedy relish this new transformative power of the body. The Lady's Voice and Ghost are plagued by this possibility. Only the men, artificers both, derive some pleasure in the body's material agency. While the play tests Senecanism and Christianity, as well as Christian stoicism, it does not anticipate Cartesianism entirely. The Lady's Voice maintains firmly, 'I am not here,' neither in the form of the Voice, nor in the form of the Ghost. She thus demonstrates that the 'cogito' moment has yet to take place. The disembodied Voice is perhaps the only way, short of telepathy, in which 'consciousness' might be represented, if such a characterization is possible (for once consciousness is 'characterized', it is always already 'embodied'). But the Lady's insistence that she is 'not here', not even in her Voice, suggests that consciousness alone does not comprise selfhood in the play.

In theatrical performance the dual role of the Lady's body as corpse and as Ghost complicate issues of casting and staging. Zimmerman argues that the same actor who played the Lady would likely have played her corpse. For 
Zimmerman this 'confuses' the 'idolatry' of the corpse, 'because the theatrical corpse can be "performed" only by a living body, layered in artifice that cannot be disassembled, what should serve as the ultimate exposé ... of the underlying horror of idolatry - the literal embrace of putrefaction — looks more like an enactment of its dynamics'. ${ }^{32}$ Thus paradoxically the very act of playing the corpse invests the body with spiritual agency. But the use of an actor also suggests an awareness of the messy complications arising from the necrophilia in the play, and Zimmerman's desire to mitigate the play's perverseness by using a live person instead of a dead one, or a thing. Zimmerman dismisses the possibility that the corpse could be a prop: 'It is also possible (although I think much less likely) that in both scenes the corpse was a dummy ... which would have altered the erotic frisson of the Tyrant's lovemaking, while emphasizing ... the artifice of theatrical performance. ${ }^{33}$ But the use of a prop does more; it clarifies both the insanity of the Tyrant's treatment of the Lady's body, and the peculiar agency of a body beyond life.

\section{The Revenger's Tragedy}

If The Maiden's Tragedy demonstrates a crisis of the body's relationship to soul, a crisis ultimately contained by the play, then The Revenger's Tragedy refuses this containment, to place the body alone at centre. The conception of soul is conspicuously absent. Furthermore, there can be no doubt about the underlying misogyny of these plays and the violence done to women's bodies. As Karin Coddon has pointed out, conceptions of gender break down in The Revenger's Tragedy: 'we know the skeleton is female only because we are told so. ${ }^{34}$ Representation itself collapses and 'the illusion of "honesty" — or mimesis - makes representation a metaphysical impossibility. And in the absence of metaphysics this theatre can proffer only the arbitrary materiality of bodies stripped even of the ostensibly stable semiotic distinctions between living and dead.' 35

If the Lady's body in The Maiden's Tragedy approaches an automaton, the skeletal body of Gloriana aligns her more clearly with Baudrillard's simulacrum, a figure that does not 'represent', or 'mimic', because it has no ties to its 'original' body as Gloriana. It is in fact as real as the former body of Gloriana, with no trace of imitation or derivation remaining. ${ }^{36}$ For Coddon, as for Kathryn Finin, the audience is complicit in the Duke's violation of the body: 'the spectators, situated in the position of viewing the prurient machinations less of mimetic characters than of objects, are themselves inscribed as 
voyeuristic necrophiles' ${ }^{37}$ But the accusation of necrophilia implies a recognition of 'deadness' by the Duke and the audience both. ${ }^{38}$

In fact dramatic irony renders only the audience and Vindice 'voyeuristic necrophiles' whereas the Duke is simply duped. Representation and mimesis in this sense do not break down entirely. For the audience to derive pleasure and/or discomfort from the anticipation of a sexual encounter between the Duke and dead body — for the dramatic irony to work — the audience must recognize the difference between dead bodies and living ones. Both the audience and Vindice are implicated further in that their pleasure is also imbricated with the Duke's initial sexual pleasure, moving thus from anticipation to fulfilment. As for the Duke, while we recognize that he is a poor reader, the skeleton never signals its own falseness to him, even after he has been poisoned for pouncing.

Ultimately, the artificer and avenger Vindice reveals to the Duke that the skeleton is anything but 'real'. The success of Vindice's revenge depends as much upon such a theatrical revelation as on the material fashioning of the skeleton Gloriana. Finin argues that Vindice's concern with aesthetics and poetic justice effaces the importance of the female body. Because revenge is here, and almost always contingent on the materially modified body, the body itself occupies centre stage, even over Vindice, who orchestrates the revenge. What is more, this play challenges conventional notions of desire and sex. On the one hand, the desirable female body is a 'dead one'; on the other, desire is shown to be dirigible and manufacturable, so that, dead or alive, the gender and the vitality of bodies do not signify. For the Duke and for Vindice, a spiritual immanence of the body is not necessary for pleasure. Metaphysical presence is thus shown to have no absolute value that technology cannot replace materially.

For many critics, the play's effacement of Gloriana points to a kind of futility and cynicism: 'Vindice, no less than the skull, functions more as a prop, as "a thing of nothing", than as an agent ... no "real Vindice" is possible in the play. ${ }^{39}$ For Coddon, the play is given over to "show and useless property" - props, things of nothing, theatrically manipulable but inherently meaningless ... bodies ... playing roles that have no ultimate reference to subjectivity - the enabling distinctions that divide mind from corporeality ... are disintegrated'. ${ }^{40}$ In fact, Coddon echoes Bosola in The Duchess of Malfi who suggests that we are all walking corpses: 'Though we are eaten up of lice, and worms, / And though continually we bear about us / A rotten and dead body, we delight / To hide it in rich tissue' (2.1.58-61). But Bosola, 
like Gloriana, Vindice, and the Lady, elucidate the ways in which, even while dead, bodies are still invested with agency. Deadness (or a simulacrum) is not equivalent to an inherent meaninglessness. Vindice himself champions his role as artificer who 'fashioned' the body of Gloriana to be agent of its own revenge: 'I have not fashioned this only for show / And useless property; no, it shall bear a part / E'en in its own revenge' (3.5.100-2). Even if 'this theatre can proffer only the arbitrary materiality of bodies' ${ }^{\prime 1}$, dead bodies signify as much as live ones.

\section{The Duchess of Malfi}

The Duchess of Malfi, like The Maiden's Tragedy, demonstrates ambivalence about the soul's immanence in the body that also emerges through the materially fashioned body as automaton. ${ }^{42}$ In this play bodies move from a world of intense vitality to a world of automata. As critics have noted, the play challenges traditional conceptions of tragedy, with significant focus on the private, domestic life of the Duchess, which contrasts with her public rule alongside her brothers: 'She has enforced a split between private and public life, establishing Antonio as ruler of the night and lord of misrule, while she rules the public world of the day ... that the exercise of Renaissance sovereignty required'. ${ }^{43}$ And, yet, as Callaghan and Wells point out, in the division between the Duchess's body and the body politic lies the power of the Duchess's body to betray her, as her belly grows, making her pregnancy and her private love affair difficult to conceal. Even though the Duchess possesses the private quality of virtue, her body is always the primary focus in the public sphere.

Indeed most of the characters, including the Duchess herself, are intensely preoccupied with her body and its material changes. The Duchess, anxious over her pregnancy weight and her greying hair, is self-conscious about remaining beautiful in the eyes of Antonio. At the end of the play, she is also concerned about the fate of her body after she is taken for execution. ${ }^{44}$ What is more, the Duchess's body and other materially fashioned bodies contribute to the issue of a divided self, calling attention to the tenuous distinction between representation (mimesis) and the real, like the skeleton Gloriana and like the Lady. The Duchess herself is the first to reveal her divided self: 'This is flesh, and blood, sir, /'Tis not the figure cut in alabaster / Kneels at my husband's tomb' (1.2.369-71). Addressing Antonio before she proposes to him, the Duchess argues that her public self is akin to the effigy by her husband's 
tomb, an imitation, a public, static, exposed figure that is incongruent with her real, fleshly, material self. Repeated references to her divided self are complicated by dissonant images of the Duchess as 'a holy relic' (3.2.138) and as a 'reverend monument' (4.2.33), images that, in contrast to the Duchess as effigy, infuse the material with the spiritual: relics and holy monuments possess a spiritual indwelling that effigies do not.

Bosola, Ferdinand, and the Cardinal also fixate on the Duchess's body. Theodora Jankowski argues that the brothers attempt to control the Duchess's political power, by monitoring her biological power. ${ }^{45}$ When Bosola is commissioned to spy on the Duchess, he describes her pregnant body:

\section{I observe our Duchess}

Is sick a-days, she pukes, her stomach seethes, The fins of her eyelids look most teeming blue, She wanes i'th' check, and waxes fat i'th' flank; And contrary to our Italian fashion, Wears a loose-bodied gown: there's somewhat in't.

According to Marian Nordfors the Duchess is 'The most realistically pregnant heroine ever put on the English stage. Bosola's description reads like a physician's journal'. ${ }^{46}$ Bosola's description in fact betrays his own disgust about the visceral elements of pregnancy — hardly the detached frankness of a physician - to reveal rather a profound revulsion at the body's own bodilyness. And yet Bosola views cosmeticized women as deceivers (2.1.25-31). Paradoxically, therefore, while Bosola repudiates cosmetics, disguises, and a focus on outward appearance, he simultaneously betrays intense repulsion when the body is undisguised and shown to be its messy, disorderly self.

If Govianus, the Tyrant, and Vindice all function as artificers to materially fashion the bodies of the Lady and Gloriana to effect revenge, then Ferdinand and the Cardinal follow suit, enacting revenge that culminates in radical corporeal fashioning. Ferdinand progressively modifies the body in more extreme ways, beginning with the mandrake root, which he digs up early in the play. ${ }^{47}$ He next creates miniature reproductions of the Duchess, finishing when he procures wax figures to replace the bodies of Antonio and the children. The brothers' role in the Duchess's 'containment' has been the subject of much scholarly work, though few have acknowledged the role of the modified body in this act of containment. ${ }^{48}$ According to Wells the wax figures are an instance of Freud's unheimliche, or 'uncanny,' which is a 
public, spectacular, demonstration of force that undermines her private world and her identity. ${ }^{49}$ These figures are also simultaneously automata. Freud's uncanny, like Cartesian automata, requires familiarity and mimesis, and is thus derivative. Ferdinand's revenge in fact depends on such familiarity.

The Maiden's Tragedy and The Revenger's Tragedy prove that theatre requires a level of materialism and that plays in performance provide different challenges to the body. When Ferdinand reveals the wax figures to the Duchess (4.1.55), both the play in production and the play as a reader's text must be considered. For readers, dramatic irony is important, since the stage directions are accessible: 'Here is discover'd, behind a traverse, the artificial figures of ANTONIO and his child; appearing as if they were dead.' In this instance, only the Duchess is tricked because the reader has knowledge of Ferdinand's methods. Presumably, like the Maiden's Tragedy, in performance the figures would be played either by actors (Antonio and the oldest son), or by dummies. Whereas for Vindice his revenge was contingent on a dramatic irony in performance, for Ferdinand and for the play's audience, the success of his revenge depends on the 'realness' of these figures. Both the Duchess and the audience must believe that Antonio and the children are dead. The wax figures thus work as automata to elicit the same (real) response as a dead Antonio and children. Bergeron suggests that when the Duchess and her children are strangled later, the revelation ('Shows the Children strangled) 'ironically counterpoints the earlier display of wax figures, for now we see the real children truly dead — life imitates art'. ${ }^{50}$ In this sense the wax figures become more than automata, approaching simulacra, since they serve as the basis for re-iteration or reproduction to become constitutive rather than derivative.

Ferdinand's delight in his revenge, moreover, is contingent on the Duchess's inability to distinguish between the wax figures and real people:

Excellent; as I would wish: she's plagu'd in art.

These presentations are but fram'd in wax

By the curious master in that quality,

Vincentio Lauriola, and she takes them

For true substantial bodies.

In an aside, Ferdinand reveals his enjoyment and the trick to the audience, creating a disjunction between the audience and the Duchess. To the Duchess's detriment, she, like the Tyrant and Duke, cannot distinguish the automata. Yet, where The Revenger's Tragedy implicates the audience alongside Vindice 
— indeed the audience relishes the revenge (perhaps squeamishly) alongside Vindice - Ferdinand's revelation creates dramatic pathos for the Duchess, and a new respect for Bosola, whose role as toady is complicated here. Despite Bosola's apparent loathing of deception and disguise, he finds it necessary to disguise himself before inflicting more torture on the Duchess, resolving to act 'Never in [his] own shape' (4.1.131). ${ }^{51}$ Bosola, moreover, reveals the trickery to the Duchess, after which she finally dies. The play remains ambiguous about the extent to which an automaton has agency (why bother revealing the trick otherwise?). Ferdinand's material punishment goes only so far.

But Bosola also demonstrates a move in opposition to the direction of the play, and in opposition to the direction of both The Maiden's Tragedy and The Revenger's Tragedy. Where the play is progressively stripped of vitality to showcase a world of automata, Bosola increasingly sheds his material fixations to come into being as a spiritual stoic:

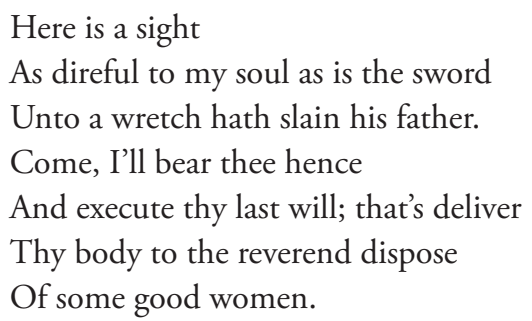

Bosola's cynicism, his material obsessions (economic and fleshy lust for the Duchess), and his obsequious capitulation to the brothers come unhinged when he becomes a true Senecan convert. The death of the children, the torture of the Duchess, and her death have the effect of gaining Bosola's sympathy, to the extent that he treats the Duchess's body with more reverence than ever before. Indeed he is more careful of her soul after her death than while she was living. Bosola relinquishes his role as 'intelligencer' to become a bonafide self-loathing stoic:

Thou are a box of worm seed, at best, but a salvatory of green mummy: what's in this flesh? A little cruded milk, fantastical puff-paste: our bodies are weaker than those paper prisons boys use to keep flies in. 
Bosola also recites the Senecan mantra: 'didst thou ever see/a lark in a cage? Such is the soul in the body'(4.2.127-128), describing the body as mere vessel, vulnerable and apt to disintegration.

The Duchess in contrast makes the transition to a new world view more completely, one that anticipates Cartesian dualism. Before Bosola's act of madmen, the Duchess attempts to rationalize her grief to Cariola and fight off despair. Yet the Duchess is still concerned with her body: 'Who do I look like now?' (4.2.31), she asks. Cariola replies, 'Like to your picture in the gallery, / A deal of life in show, but none in practice: / Or rather like some reverend monument'(4.2.31-33). Here the Duchess is caught between two world views, one in which she is a monument infused with spirit, and another in which she is reified, made into a thing. That Cariola's first instinct is to describe the Duchess as a painting of herself is revealing in that 'reverend monument' seems an afterthought, to mitigate the implications of her first impulse. Similarly, before her execution, the Duchess is more apprehensive about her body than her 'soul': 'Dispose my breath how please you, but my body / Bestow upon my women, will you?' This passage echoes the Tyrant's claim regarding the Lady ('The house is hers the soul is but a tenant'), and demonstrates that the Duchess clings stubbornly to her body. Indeed the Duchess shows little worry for her soul, but suggests that her body's handling is the more important.

The Duchess's self is further tested because she figures in this play as an Echo of herself, but one that does not have the same effect of doubling as the Lady's Ghost, inasmuch as the corpse of the Duchess and her Echo are never present simultaneously (neither in the text nor on stage). Moreover, the Duchess's body is never fashioned in any way, which suggests that this play privileges bodily wholeness. Delio and Antonio encounter the Echo behind the Cardinal's abbey:

Antonio Echo, I will not talk with thee;

For thou art a dead thing.

Echo Thou are a dead thing.

Antonio

My Duchess is asleep now,

And her little ones, I hope sweetly: oh Heaven

Shall I never see her more?

Echo Never see her more. 
The rhetorical progression of this passage, a moment of occupatio (or apophasis), actually brings about Antonio's complicity with a viewpoint he initially refutes. Antonio insists that as a 'dead thing' the Echo ought not to have agency, but in answering the Echo, and then in asking the Echo a question, affirms the authority of the bodiless Echo. While the Echo might represent the soul of the Duchess, it presents a similar problem as the Voice of the Lady: the Echo impossibly represents 'consciousness', which cannot happen a priori vocalization. Yet, the Echo possesses agency beyond the life of the Duchess to warn Antonio of the dangers ahead.

If the relationship between the body and soul is fraught in revenge plays, only The Maiden's Tragedy and The Duchess of Malfi attempt to manage the issue. Both plays demonstrate profound discomfort with the body's evacuation of spirit. Yet while The Duchess's body is a central focus, that body is preserved as whole, never modified by any artificer. What is more, she is ultimately divorced from her entire body as disembodied echo, a conspicuous Cartesian characterization of selfhood as comprised by the cogito. The Lady's body and Gloriana's are not so privileged. Both suffer sexual violation and death, though their bodies, too, are ultimately left whole. As automata, both the Lady's body and Gloriana demonstrate the body to have an unruly agency, which the Lady's Ghost tries desperately to police. Like The Duchess of Malfi, The Maiden's Tragedy provides other possibilities for the location of the self. The Lady insists, problematically, that some of her self inheres in her body. Indeed her material body governs her spirit. Although the play remains ambivalent about the soul's immanence in the body, it attempts to reconcile the two, with the Lady's Ghost and corpse united in the final scene. Yet, this is very much a sorry scene. While there is a sense of relief that the Lady's body will be spared further abuse, the play fails to manage the exorbitantly maniacal acts of the artificers, or the radical division of the Lady's self. That the Tyrant dies at the hands of Govianus is small consolation, moreover, since Govianus survives ultimately, and since he himself becomes an artificer of the Lady's body, rather than stoic avenger.

These later plays in their seriousness anticipate the more sterile forms of automata of the late early modern period, which revive both the allegory and the morality tale, so that the body is frequently (re)invested with spiritual significance. Perhaps because of The Revenger's Tragedy's playful and cavalier attitude towards the body, later texts seek to moralize. The earliest of the Jacobean plays, The Revenger's Tragedy is ultimately unconcerned with the relationship between body and soul. The body alone takes centre stage. And the 
body alone is endowed with an obstreperous agency that effectively upstages both the Duke and Vindice in its materialism. Vindice as artificer gives way to Gloriana the fashioned skeleton to be her own agent of revenge, a complete devotion to the power of the body over the soul.

\section{Notes}

A special thanks to Helen Ostovich, the anonymous readers at Early Theatre, Elizabeth Hanson, Margaret Pappano, Marta Straznicky, and Mary Nyquist whose feedback and criticism have been invaluable.

1 I cite from Thomas Middleton, 'The Maiden's Tragedy', Four Jacobean Sex Tragedies, ed. Martin Wiggins (Oxford, 1998), 161-232. The Maiden's Tragedy has been the focus of much critical discussion of late. At the 'Renaissance Drama in Action' Conference at the University of Toronto (Oct. 2008), I participated in a workshop, entitled, 'Animating the Text: Performing Corpses and their Spirits in Early English Drama,' which problematized the corpse and the Ghost of the Lady who appear on stage together. Susan Zimmerman, The Early Modern Corpse and Shakespeare's Theatre (Edinburgh, 2007), discusses the extent to which the Lady's corpse is an idol. See also 'Animating Matter: The Corpse as Idol in The Second Maiden's Tragedy,' Renaissance Drama 31 (2002): 215-43.

2 For a discussion of death and dead bodies see Mary Floyd-Wilson and Matthew Greenfield, Gail Kern Paster, Tanya Pollard, Katherine Rowe and Julian Yates, 'Shakespeare and Embodiment: An E-Conversation,' Literature Compass 2 (2005), 1-13. For Richard Strier discussions of dualism in the Renaissance are not anachronistic, but appropriate to describe Renaissance phenomena such as disembodied souls; see Richard Strier and Carla Mazzio, 'Two Responses to 'Shakespeare and Embodiment: An E-Conversation,' Literature Compass 3.1 (2005), 15-31. Carol Chillington Rutter, Enter the Body: Women and Representation on Shakespeare's Stage (New York and London, 2001) discusses Cordelia's body on stage in King Lear.

3 Erica Harth, Cartesian Women: Versions and Subversions of Rational Discourse in the Old Regime (Ithaca and London, 1992), 74. Gordon Braden, Renaissance Tragedy and the Senecan Tradition (New Haven, 1985), 146.

4 Caroline Walker Bynum, The Resurrection of the Body in Western Christianity, 2001336 (New York, 1995), 11, has made a similar claim about medieval accounts of resurrection, arguing for evidence of material fixation over spiritual concern.

5 Elaine Scarry, 'Donne: "But yet the body is his booke", Elaine Scarry (ed.), Literature and the Body: Essays on Population and Persons (Baltimore, 1987), 107 n.22. 
Scholarship on the early modern body has also focussed the body as comprised of parts that occupy the positions of subject and object. Katherine Rowe, Dead Hands: Fictions of Agency Renaissance to Modern, (Stanford, 1999), discusses the dead hand as a subject. Body parts are also subjected as 'isolated and disempowered', argue David Hillman and Carla Mazzio (eds), The Body in Parts: Fantasies of Corporeality in Early Modern Europe, (New York and London, 1997), xix. Moreover, there is much scholarship on the partitioned body in poetry as blazon, and in anatomy, through the 'culture of dissection'; see Jonathan Sawday, The Body Emblazoned: Dissection and the Human Body in Renaissance Culture (London and New York, 1995).

6 I quote from Thomas Kyd, The Spanish Tragedy, ed. Katherine Eisaman Maus, Four Revenge Tragedies (Oxford, 1995), 1-91. For more on Senecanism and revengers, see Maus 'Introduction', Four Revenge Tragedies, ix-xxxi, as well as Foakes, 'Introduction' to his edition of Thomas Middleton, The Revenger's Tragedy (Manchester and New York, 1996), 1-28.

7 Seneca’s Epistle 65, Lucius Annaeus Seneca, Letters from a Stoic: Epistulae Morales ad Lucilium, trans. Robin Campbell (Middlesex, 1969), 123-34.

8 Seneca, who endured physical and emotional torture under Nero's reign, believed his suicide to be the last recalcitrant act of his freedom, freeing his soul from his body. See letter 70, Lucius Annaeus Seneca, Seneca's Letters to Lucilius, 2 vols, trans. E. Phillips Barker (Oxford, 1932), 1:240-1.See also Tacitus' famous account of Seneca's death: ibid, 243. Letters 54, 61, 68, 70 and 77, among others, also discuss death. English revenge tragedies eliminate the suicide convention of Seneca's plays.

9 Zimmerman, The Early Modern Corpse; Zimmerman, 'Animating Matter'.

10 Where some critics (Lancashire and Wiggins, among others) argue for the ways in which revenge plays are politically conservative and religiously orthodox, others (Dollimore, Maus, and Lever) argue for the religious and political subversion suggested by the texts. Anne Lancashire 'The Second Maiden's Tragedy: A Jacobean Saint's Life', The Review of English Studies 25 (1974), 267-79; Lancashire, The Second Maiden's Tragedy (Baltimore, 1978); Martin Wiggins, 'Introduction', Four Jacobean Sex Tragedies (Oxford, 1998), vii-xxi; Jonathan Dollimore, Radical Tragedy, $2^{\text {nd }}$ edn (New York, 1989), 139-52; J.W. Lever, 'Tragedy and State', Stevie Simkin (ed.), Revenge Tragedy (Basingstoke, 2001), 24-40; and in the same volume, Katherine Maus, 'The Spanish Tragedy, or, The Machiavel's Revenge', 88-106.

11 Braden, Renaissance Tragedy, 203.

12 Maus 'The Spanish Tragedy',101.

13 While he is most known for the division of mind and body, and clarifies that the 'mind' and 'soul' are to be considered separately (86), Descartes often uses the word 
'soul' interchangeably with 'mind'; see René Descartes, Meditations and Other Metaphysical Writings, trans. Desmond M. Clarke (London, 2000), 79, 84, 187, 193.

14 Braden, Renaissance Tragedy, 146.

15 Harth, Cartesian Women, 74.

16 Ibid, 74. The Cartesian deductive method, which is dependent on a process of doubt, requires material proof (though it also requires rationalism of the mind to doubt away all evidence to the contrary).

17 Descartes qtd in Drew Leder, 'A Tale of Two Bodies: the Cartesian Corpse and the Lived Body', Donn Welton (ed.), Bodies and Flesh: A Philosophical Reader (Oxford, 1998), 119.

18 In De Motu Cordis et Sanguinis (1628) Harvey writes, 'These two motions, one of the ventricles, another of the auricles, take place ... in such a manner that there is a kind of harmony or rhythm ... Nor is this for any other reason than it is in a piece of machinery ... or in that mechanical contrivance which is adapted to firearms, where the trigger being touched, down comes the flint, strikes against the steel, elicits a spark ... causes the explosion, propels the ball, and the mark is attained'. William Harvey, 'On the Motion of the Heart and Blood in Animals', Logan Clendening (ed.), Source book of Medical History (New York, 1942), 161. Many thanks to David Jackson who reminded me about Descartes' discussion of 'pumps'.

19 Albert Howard Carter III, Our Human Hearts: A Medical and Cultural Journey (Kent, 2006), 31-2.

20 Leder, 'A Tale of Two Bodies', 119. Descartes apparently tried to create his own automaton 'in the likeness of a young girl which could make some human-like noises and move its limbs'; see Dave Robinson and Chris Garratt, Introducing Descartes (Cambridge, 1999), 102.

21 James Sanford, respected Elizabethan translator, translated Agrippa's Vanitate into English in 1569; its popularity led to a second edition in 1575. It was later retranslated by Roger L'Estrange in 1676, with several more editions in 1684 and 1689. Agrippa's Three Books of Occult Philosophy $(1650,1651)$ and His Fourth Book of Occult Philosophy $(1655,1665,1772,1783)$ were also published in several editions. All versions of Vanitate that I have seen are octavos, which further attests to their accessibility.

22 Agrippa, Vanitate, 1569: 55-6.

23 Ibid, 55.

24 Ibid, 1684:113.

25 Thomas Coryate, Coryat's Crudities, 2 vols (Glasgow, 1905), 1:393. Recently there has been scholarly interest in automata. Jonathan Sawday discusses Talus from Book $\mathrm{V}$ of Spenser's Faerie Queene, suggesting that automata come second to a notion 
of the body, but that bodies are sometimes described as machines. Jonathan Sawday, "Forms Such as Never Were in Nature": the Renaissance Cyborg', Erica Fudge, Ruth Gilbert and Susan Wiseman (eds), At the Borders of the Human: Beasts, Bodies and Natural Philosophy in the Early Modern Period (London, 1999), 171-195. Jessica Wolfe suggests that Talus is a machine, which challenges all of Spenser's heroic ideals. Jessica Wolfe, Humanism, Machinery and Renaissance Literature (Cambridge, 2004), 203-235. Adam Max Cohen, Shakespeare and Technology: Dramatizing Early Modern Technological Revolutions, (New York, 2006), 3, acknowledges the ways in which individuals 'turn tech' in the Renaissance. His primary focus is not on the human body as automaton, but rather on print technologies and the 'horological revolution'. See also 'Automaton', Oxford English Dictionary Online, 25 October 2005 <http://dictionary. oed.com/cgi/entry/>.

26 Beaumont and Fletcher are cited next by the $O E D$ for their use of 'automaton' in the revenge tragedy The Bloody Brother. Latorch describes "A true Automaton:'(4.2.212) and claims to have seen others (4.3.221-23). J.D. Jump notes that Beaumont and Fletcher have taken their descriptions of automata directly from Cornelius Agrippa.

27 Ovid's story of Pygmalion, who falls in love with a statue he creates, is the classical model which lacks the disturbing effects of this play. On cosmetics in revenge plays see Farah Karim-Cooper, Cosmetics in Shakespearean and Renaissance Drama (Edinburgh, 2006), 75-88.

28 Kevin Crawford's coinage, for which I am indebted: Crawford, 'Softened Masculinity',105. The contest is over only because Govianus is the last man standing.

29 Lancashire, 'A Jacobean Saint's Life', 277; Marion Lomax, 'The Faerie Queene and The Book of Revelation as Sources for Spectacle in The Second Maiden's Tragedy', Notes and Queries 231 (1986), 378-9. Thanks to Elizabeth Hanson who pointed out that the Lady echoes Jesus when Mary Magdalene comes to his tomb.

30 Zimmerman and Bynum both discuss revenants, beings who wander the earth as spirits because their bodies remain unburied (Zimmerman, Early Modern Corpse, 96-120).

31 Zimmerman, 'Animating Matter', 234.

32 Ibid, 235.

33 Ibid, 243. David M. Bergeron argues for the use of a prop, citing Russell Brown. The play was first performed by the King's Men in 1611 and licensed for stage by George Buc on October 31, 1611. Bergeron uses the staging of other plays at this time, such as The Duchess of Malfi and The Winter's Tale as evidence, since all used wax figures, and took cues from Sidney's Arcadia. See David M. Bergeron, 'The Wax Figures in The Duchess of Malfi, SEL 18 (1978), 331-9. 
34 Karin S. Coddon, "For Show or Useless Property": Necrophilia and The Revenger's Tragedy', Simkin (ed.), Revenge Tragedy, 121. There is much valuable scholarship dedicated to the problematic treatment of women in both The Maiden's Tragedy and The Revenger's Tragedy. Kevin Crawford has argued that the Tyrant and Govianus construct their manhood through the use of Lady's body. Crawford, 'Softened Masculinity', 113; Kathryn Finin, 'Re-Membering Gloriana: "Wild Justice” and the Female Body in The Revenger's Tragedy', Renaissance Forum: An Electronic Journal of Early Modern Literary and Historical Studies 6 (2003), par 34, explicates the reader's/audience's participation in Vindice's revenge and refutes arguments about female agency. See also Coddon, who notes, 'the emblematic desirable female body is a dead one, spectacularly displayed to appraising, evaluating male gazes' (132). Aimee Elizabeth Ross, 'From Ghosts to Skulls: Selfhood, Bodies and Gender in Renaissance Revenge Tragedy', PhD thesis (University of Oregon, 2000), 258, writes, 'revenge tragedy rejects the disembodied male ghost in favor of the dead female body as the impetus for revenge'.

35 Coddon, 'Necrophilia and The Revenger's Tragedy', 130-1.

36 It is sometimes hard to believe that the Duke would fall for such a seemingly 'obvious' ploy, but perhaps easier to understand when read alongside contemporary phenomena such as 'RealDoll' <www.realdoll.com>, a sex doll that is 'lifelike'. Testimonials on the RealDoll website use the discourse of love. Men who have purchased RealDolls describe their relationships with the dolls as no different than ones with women. A Recent film, Lars and the Real Girl (2007), explores such a relationship.

37 Coddon, 'Necrophilia and The Revenger's Tragedy', 131.

38 The Duke's expectations for the prostitute as a purely mechanical form of sex means that he would always already privilege the material body of the prostitute and the mechanical act of sex. Thanks to Archana Rampure who pointed this out to me.

39 Coddon, 'Necrophilia and The Revenger's Tragedy, 130.

40 Ibid, 136.

41 Ibid, 131.

42 I quote from John Webster, The Duchess of Malfi, ed. Elizabeth M. Brennan (London and New York, 1993). The Duchess of Malfi features the fashioning of a man's body, which is a rarity. However the male body is afforded privileges that the female body is not. Most noticeably, Antonio's actual body is never modified and never suffers violence, like the Lady's body, or Gloriana's body.

43 Susan Wells, 'Dominance of the Typical and The Duchess of Malfi', Dympna Callaghan (ed.), The Duchess of Malfi; Contemporary Critical Essays (London, 2000), 147. According to Callaghan, the Duchess as a widow possesses more power than both unmarried and married women; see her 'Introduction' to this essay collection, 7. 
44 At 4.2.224-5, the Duchess requests her body be given to her women after she is killed. At 5.2.139 we also learn that the Duchess's picture and form have been reproduced in miniatures for the public; see Brennan's edition, cited above.

45 Theodora A. Jankowski, 'Defining/Confining the Duchess: Negotiating the Female Body in John Webster's The Duchess of Malfi, Callaghan (ed.), The Duchess of Malfi, 85.

46 Marion Nordfors, qtd in Brennan (ed.), Duchess of Malfi, 34 n.66-74.

47 The Mandrake 'has a forked root, and thus resembles the human form. Supposed to grow under the gallows, it was said to shriek when pulled from the ground' (bid, 50). At 4.2.231, the Duchess also calls for mandrake to put her to sleep before her strangling.

48 McLuskie suggests the Cardinal's dumb show polices the Duchess's sexuality. Kathleen McLuskie, 'Drama and Sexual Politics: the Case of Websster's Duchess', Callaghan (ed.), The Duchess of Malfi, 104-21. Much work focuses on Ferdinand's incestuous desire and his inability to tolerate female rule. Susan Wells, 'Dominance of the Typical', 154, highlights Ferdinand's verbal insertion of 'the phallus'.

49 Ibid, 157-8.

50 Bergeron, 'The Wax Figures', 336.

51 Antonio is of course a fully realized Senecan, who would never change his shape despite potentially fatal consequences: 'It may be that the sudden apprehension/ Of danger (for I'll go in my own shape)' (5.2.67-8). 
